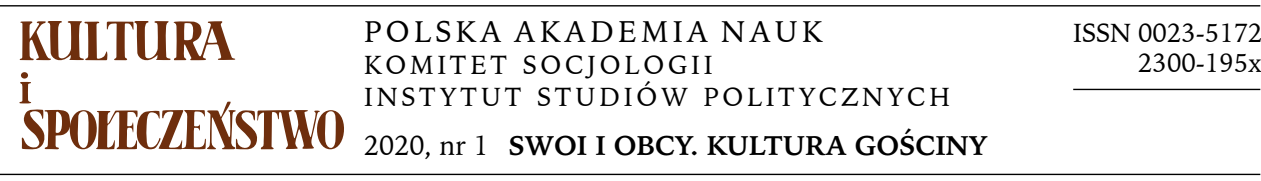
$\begin{array}{llllllll}A & R & T & Y & K & U & 亡 & Y\end{array}$
I
$\begin{array}{llllllll}\mathrm{R} & \mathrm{O} & \mathrm{Z} & \mathrm{P} & \mathrm{R} & \mathrm{A} & \mathrm{W} & \mathrm{Y}\end{array}$

BOGUMIŁA MATEJA-JAWORSKA

Uniwersytet im. Adama Mickiewicza

\title{
KOBIECA GOŚCINNOŚĆ? ANALIZA WYBRANYCH PRAKTYK GOSZCZENIA
}

Choć trudno byłoby uznać, że kwestie dotyczące gościny i gościnności znajdują się w centrum zainteresowania nauk społecznych i humanistycznych, bliższe przyjrzenie się tej tematyce pokazuje, że można je odnaleźć w kluczowych zagadnieniach dotyczących relacji społecznych. Przekonania na temat gościny, a także tworzone na ich podstawie normy, współkształtowały i współcześnie nadal współkształtują wiele praktyk społecznych. Tracy McNulty (2007, s. vii) zauważa, że możemy śledzić, jakie przemiany przechodziła ta sfera wraz $z$ rozwojem cywilizacji zachodniej: zajmowała ona poczesne miejsce $\mathrm{w}$ prawie każdej religii (jako przymiot bogów), pojawiała się w rozważaniach filozofów (m.in. u Platona czy Immanuela Kanta), a obecnie także w opracowaniach dotyczących turystyki i ekonomicznego aspektu goszczenia. W kulturze polskiej zagadnienia gościnności są tym bardziej istotne, że - jak pokazują badania - nadal stanowią istotny element autostereotypu narodowego. W sondażu Kantar Public, przeprowadzonym na zlecenie „Polityki” w lipcu 2017 roku na reprezentatywnej próbie tysiąca badanych, gościnność jako cechę Polaków wskazywano najczęściej spośród wszystkich przedstawionych respondentom do oceny cech (za charakteryzującą Polaków w dużym lub bardzo dużym stopniu uznawało ją aż $77 \%$ ankietowanych). Gdy to samo pytanie sformułowano w inny sposób, prosząc o wybór spośród dwunastu naj- 
bardziej typowych dla naszych rodaków cech jedynie czterech, gościnność ponownie zajęła pierwsze miejsce - ze wskazaniami $63 \%$ respondentów. Co ciekawe, w tej wersji pytania przeważyły głosy kobiet (69\% pań i 56\% panów), gdyż mężczyźni najchętniej uznawali, że Polacy są pracowici.

Już tak zwięzłe zarysowanie kontekstu pozwala zrozumieć, że doniosłość społecznych implikacji zjawiska gościny w znaczącej mierze opiera się na regulowaniu kwestii dotyczących relacji między „swoimi” a „obcymi”, na tym, jaki jest kulturowo pożądany sposób podejścia do nich. Gościnność z jednej strony zatem uchyla granice (poprzez dopuszczenie „obcych” do wspólnoty), z drugiej jednak - paradoksalnie - je utwierdza, definiując, kim jesteśmy „my”, a kim „oni”, porządkując tym samym rzeczywistość. Co więcej, zaproszenie gościa do własnego domu stanowi uchylenie granic także $\mathrm{w}$ bardziej dosłownym, przestrzennym sensie - między tym, co publiczne i prywatne. Jednak dopuszczenie „obcego" do sfery domowej także odbywa się zwykle na ściśle określonych warunkach (np. ma on dostęp tylko do wybranej części mieszkania, musi przestrzegać pewnych norm; zob. np. Brzozowska-Brywczyńska 2019; Skowrońska 2019), które często bardzo wyraźnie kreślą linie podziału mimo zapewnień o otwartości i hasła, by „czuć się jak u siebie".

Chciałabym tu podjąć ten wątek rozważań nad gościną, odnosząc go do wybranych praktyk goszczenia realizowanych przez kobiety i mężczyzn. Jeśli bowiem za niezwykle istotną dla funkcjonowania społecznego można uznać dychotomię „swój”-„obcy”, to równie ważne konsekwencje ma ciągle powszechnie używany podział ze względu na płeć rozumianą jako dwie wykluczające się kategorie (zob. np. Bourdieu 2004; Jakubowska 2013). Dzieje się tak, chociaż badania często wskazują, że płeć należałoby raczej ujmować jako kontinuum (zob. Jakubowska 2012, s. 75-76). Wydaje się, że zestawienie i analiza opisywanych wcześniej dychotomii („swój”-„obcy”, „my”-,oni”, publiczne-prywatne, „męskie”-,,kobiece”) może ujawnić interesujące punkty styku i podobieństwa. Warto już na wstępie zauważyć (choć będzie o tym jeszcze mowa), że podziałowi na to, co publiczne (to, co na zewnątrz, pozadomowe) i prywatne (to, co domowe) od stuleci w kulturze zachodniej towarzyszy podział na „męską" i „kobiecą” strefę wpływów. Gościnność, rozumiana jako przyjmowanie odwiedzających we własnym mieszkaniu, stanowi zatem fenomen, który obejmuje wszystkie wskazane dychotomie.

Materiałem badawczym, który stanowi podstawę rozważań, są transkrypcje 60 wywiadów pogłębionych, które zrealizowali członkowie ze- 
społu Archiwum Badań nad Życiem Codziennym ${ }^{1}$ na przełomie 2017 i 2018 roku w trzech miastach województwa lubuskiego ${ }^{2}$. Scenariusz wywiadu dotyczył przede wszystkim praktyk odwiedzania i przyjmowania gości w domu oraz sposobów rozumienia gościny. Rozmowy przeprowadzono z 39 kobietami i 21 mężczyznami, w różnym wieku (od nastolatków po emerytów). Ze względu na trudności związane z rekrutacją, wśród respondentów przeważały osoby z wysokim kapitałem kulturowym, co zostało wzięte pod uwagę podczas interpretacji wyników (4 respondentów miało wykształcenie podstawowe lub gimnazjalne, 5 osób - zawodowe, 17 badanych ukończyło szkołę średnią, a aż 34 - studia wyższe). Kilka osób przyznało, że korzystają z pomocy opieki społecznej, a ich warunki mieszkaniowe są bardzo złe, jednak zdecydowana większość raczej nie miała problemów finansowych. Końcowe wnioski zatem w przeważającej mierze dotyczą przedstawicieli szeroko rozumianej klasy średniej ${ }^{3}$.

Kontekst teoretyczny przedstawianych wyników badań stanowią przede wszystkim prace Pierre'a Bourdieu (zwłaszcza 2004, 2005, 2007) i Jeana-Claude'a Kaufmanna $(2004,2007)$ oraz ustalenia polskich autorów, którzy te koncepcje omawiali i wykorzystywali, podnosząc podobne tematy (m.in. Magdaleny Żadkowskiej [2012, 2016]; Filipa Schmidta [2010, 2015] czy Marty Skowrońskiej [2015]), lub zajmowali się tematyką gościnności (Adam Pisarek [2016], Dorota Rancew-Sikora i Magdalena Żadkowska [2017], praca zbiorowa pod redakcją Bogumily Matei-Jaworskiej i Marty Skowrońskiej [2019]). Tekst zawiera także odwołania do wybranych koncepcji badaczek z zakresu gender studies - Lucy Irigaray (2016), Elżbiety Korolczuk (2019) oraz Harriet Bjerrum Nielsen i Monicy Rudberg (1993). Wymienione publikacje, choć składają się na dość eklektyczną ca-

${ }^{1}$ Projekt Archiwum Badań nad Życiem Codziennym (ABnŻC), nr 0065/NPRH3/H11/ 82/20, był realizowany w latach 2014-2019 pod kierownictwem Marka Krajewskiego przy Instytucie Socjologii UAM. Zadanie gromadzenia, udostępnienia szerokiej publiczności, a także wytwarzania materiałów badawczych, które kontynuują wybrane tradycje polskich badań nad codziennością, zostało dofinansowane dzięki Narodowemu Programowi Rozwoju Humanistyki. Transkrypcje z opisywanych badań dotyczących gościnności dostępne są na stronie internetowej Archiwum (http://archiwum.edu.pl/dlibra/publication/557449\#structure [dostęp: 31.12.2019]).

2 Miejscowości te zostały tak dobrane, by mimo podobnej wielkości (miasta do 20 tys. mieszkańców) jak najbardziej różniły się między sobą (uwzględniono między innymi odległość od głównych szlaków komunikacyjnych, zamożność mieszkańców, wydatki na kulturę).

${ }^{3}$ Za pomocą programu MAXQDA analizie i dalszej interpretacji poddano transkrypcje ze wszystkich 60 wywiadów. Po przypisaniu wstępnych kodów fragmentom transkrypcji, w których pojawiały się zagadnienia dotyczące płci - następnie sortowano je i syntetyzowano (zob. Charmaz 2009, s. 79). 
łość i różnią się co do przyjmowanych założeń, pomagają w pełniejszy sposób zrozumieć przedstawiane wyniki.

\section{ON, ONA I GOŚCINA}

W eseju zatytułowanym Ku wzajemnej gościnności Lucy Irigaray (2016) rozróżnia kultury o męskim rodowodzie (które według niej narzuciły sztuczne granice, podzieliły gatunek ludzki, w rezultacie czego ich gościnność przesycona jest paternalizmem i postrzeganiem obcych jako posiadających gorszą pozycję) i te o rodowodzie kobiecym (w których gościnność jest traktowana jako coś naturalnego, a wszyscy postrzegani są jako dzieci tej samej matki, w szczególności matki natury). Irigaray sądzi, że dawna, starożytna praktyka wzajemnej gościnności: udzielania sobie nawzajem miejsca i ochrony - która lepiej pasowałaby do współczesnych wielokulturowych czasów - została wyparta przez takie rozumienie gościnności, które zakłada jednostronność gestu dobroczynności. Choć teza o źródłach postrzegania gościnności i rekomendacje Irigaray mogą budzić kontrowersje, trudno zaprzeczyć, że współcześnie żyjemy w kulturze, w której występuje asymetryczność relacji między przyjmującym/przyjmującą/przyjmującymi a gościem (potwierdziły to także badania przeprowadzona przez zespół ABnŻC — zob. Skowrońska 2019; Brzozowska-Brywczyńska 2019).

W ten model asymetrycznej relacji wpisują się zwyczaje i normy dotyczące gospodyń i gospodarzy we wsi Łąka przedstawione na podstawie badań etnograficznych przez Adama Pisarka (autora chyba jedynej na polskim rynku wydawniczym monografii poświęconej gościnności). Wyraźnie ukazują też odmienne postrzeganie kobiecych i męskich ról. Gospodarz ma być przede wszystkim „uczynny, szczery, otwarty, wesoły, hojny, skromny, z ogładą. Powinien miło przywitać gościa, przygotować coś do przekąszenia, zabawić rozmową. Powinien się gościem zaopiekować i wziąć za niego odpowiedzialność, a wszystko to całkowicie bezinteresownie" (Pisarek 2016, s. 115). Dobra gospodyni natomiast, według łączan, „powinna zajmować się kuchnią, przygotowywaniem posiłków, a później również prowadzeniem rozmowy - tym wyraża swoje zaangażowanie w relacje, szacunek względem przybyłych i przyjazny charakter domu" (Pisarek 2016, s. 115).

Co ciekawe, podobne przekonania na temat kobiecego ideału gospodyni odnajdziemy w zupełnie innym środowisku, wśród polsko-norweskich par analizowanych przez Dorotę Rancew-Sikorę i Magdalenę Żadkowską (2017). Opisane związki polskich kobiet i norweskich mężczyzn stanęły przed koniecznością mediowania zderzających się ze sobą z jednej strony wzorców gościny charakterystycznych dla obu kultur, a z drugiej - wy- 
obrażeń o sposobach pełnienia ról płciowych (Rancew-Sikora, Żadkowska 2017 , s. 73). Z przedstawionych badań wyłania się obraz kultury polskiej jako preferującej zdecydowanie bardziej asymetryczny model relacji z gośćmi, w którym to „zapewnianie opieki” jest znacznie istotniejsze niż „dawanie swobody”, by gość czuł się dobrze (por. Skowrońska 2019). Interpretując przytaczane przez autorki wypowiedzi respondentek można zauważyć, jak sieć kulturowych skojarzeń prowadzi zwykle gospodynie do tego, że na poziomie praktyk owa opieka nad gościem zaczyna przypominać „matczyną troskę”. Można zatem założyć, że wyobrażenie o idealnej gospodyni jest bardzo bliskie wzorowi Matki-Polki. Wydaje się, że właśnie ten silny nacisk na opiekę $\mathrm{w}$ przypadku polskiej gościnności, w połączeniu z szeroko rozpowszechnionym w naszej kulturze przekonaniem, że za opiekę odpowiedzialne są przede wszystkim kobiety, dowodzi, iż gościnę warto analizować właśnie z perspektywy genderowej. Asymetryczność relacji „swój”-„obcy”, gospodarze-goście, łączy się bowiem w naszej kulturze z wyraźnie odmiennie zarysowanymi rolami gospodarza i gospodyni.

\section{JAKA MATKA, TAKA CÓRKA?}

Analiza przeprowadzonych wywiadów wpisuje się w przytaczane wcześniej wyniki sondaży: dla zdecydowanej większości respondentów gościnność pozostaje istotnym elementem autostereotypu. Jednocześnie bliższe przyjrzenie się wypowiedziom ujawniało wyraźnie kobiecy wątek tego zjawiska. Wspominanie — często nieco mimochodem — o tym, ,jak gościła moja mama i babcia", pojawiało się przede wszystkim w opowieściach kobiet, zarówno młodych, jak i starszych, ale zdarzało się także mężczyznom. Znacznie rzadsze natomiast było powoływanie się na tradycję przekazywaną przez męskich członków rodziny. Zwykle pojawiali się oni w szerszym kontekście - tego, co ogólniej „wyniosło się z domu”, jacy wspólnie byli rodzice.

No tak zostałam też wychowana. Tak zostałam nauczona przez moja mame, że powinno się gości szanować, dbać o nich $i$ ja też zawsze jestem szanowana $i$ dba o mnie np. moja rodzina, kiedy ja ich odwiedzam i tak po prostu takie wartości wyniostam $z$ domu. [...] Nie potrafitabym przyją́ w bałaganie. To też wyniostam $z$ domu. Moja mama zawsze bardzo sprzątała, kiedy ktoś miat przyjść do domu. [...] Tak mi się zawsze kojarza polskie imprezy, np. u mnie $w$ rodzinie tak jest, że stoty aż się uginaja. Ja też przejełam te tradycje po moich babciach, prababciach, ciociach, mamach $i$... i u mnie też tak jest, że stót się ugina. [K,29,wyższe ${ }^{4}$

\footnotetext{
${ }^{4}$ Nawiasy kwadratowe zawierają informacje o płci, wieku i wykształceniu osób badanych.
} Wszystkie podkreślenia w cytatach - B.M.J. 
No obserwuje moja mamę, tak, na przykład. Jak ona nas gości. No jest cudowna gospodynia. Jest cudowna, o każdego dba. Każdemu stara się dogodzić. Po prostu no jest przecudowna. No w ogóle rodzice moi sa fantastyczni, jeśli chodzi, bo goszcza nas praktycznie co roku na święta, ale nie tylko. Ale na święta, no nie, nie było takiej tej, że my się nie spotkaliśmy, tak. Tak że no cudowni sa jako gospodarze. I ja się uczę od nich jakby. I też się staram jakby być taka jak moja mama. [K,37,wyższe]

Jeżeli się spodziewam kogoś, że ktoś wpadnie na kawkę, to staram się, żeby ciastko byto albo placuszek. To tak jak jest u mojej mamy, jak się wie, że moja siostra przyjeżdża, to musi być obiad na dwa dni przygotowany. Nie tak, że kanapka z szynka, tylko na tym talerzu musi być taka szynka i taka. Dzieci lubia ser królewski, to musi być ser królewski. [K,38,średnie]

Przytoczone cytaty pokazują kobiecą transmisję pokoleniową takiego wzoru gościnności, który utarł się w polskiej kulturze, a którego głównym elementem stała się figura „uginających się stołów” (por. Krajewski 2019). Taka tradycja, wręcz nadmiarowego przygotowywania potraw dla gości, w świetle większości wypowiedzi wydaje się nadal aktualna, w dużej mierze w wyniku skutecznej socjalizacji młodego pokolenia kobiet przez starsze. Kolejny raz nasuwa się tutaj skojarzenie z ideałem Matki-Polki: karmicielki, która jednocześnie przekazuje cenne wartości narodowe. Także w tym przypadku to, co duchowe i co jest elementem autostereotypu narodowego - traktowanie $z$ szacunkiem gości - jest łączone (wręcz utożsamiane) z roztoczeniem opieki przez zapewnienie obfitości pożywienia.

Przywiązanie kobiet do takiego wzorca gościnności zastanawia, gdy zdamy sobie sprawę z pewnych okoliczności. Po pierwsze, gdy zauważymy, jak wielkiego zaangażowania, nakładów czasu, pracy i środków wymaga tak obfite zastawienie stołu, co zwykle obarcza właśnie kobiety. Po drugie, gdy uświadomimy sobie, że do bardziej ukrytych kosztów czynienia zadość tej tradycji często należy również ograniczenie płynącej z przyjmowania gości przyjemności, jaką dla prawie wszystkich badanych kobiet stanowiła rozmowa z zaproszonymi osobami (zob. Mateja-Jaworska 2019). Jest to wynikiem nieustannego krążenia między kuchnią a stołem (głównymi arenami większości przyjęć) oraz zmęczenia odczuwanego po maratonie prac kulinarnych. Ta sama młoda respondentka, która w zamieszczonym wcześniej cytacie powoływała się na długą linię babć, ciotek i mamy, które zawsze dbały o „uginający się stół”, w innej części wywiadu przyznała, że bywa tak zmęczona, iż trudno jej uczestniczyć w dyskusjach z gośćmi.

[...] dla mnie najgorsze jest to, że ja jestem po prostu zmęczona. Bo ja przygotowuje, załóżmy, od siódmej rano w kuchni. Dzień wcześniej też. Ja zawsze po prostu: zastaw się, a postaw się! I ja po prostu o 22 czuję piasek w oczach. I... wiem, że muszę siedzieć 
i rozmawiać. Być aktywna, zaproponować herbate, podgrzać jedzenie, tak? A już po prostu nie mam na to sity. [K,29,wyższe]

Po trzecie wreszcie, weźmy pod uwagę, że na poziomie deklaratywnym największa część respondentów twierdziła, że aspekt kulinarny jest, co prawda, istotny (choć często zastrzegano, że wystarczyłoby jedynie podać: kawę/herbatę, coś słodkiego do kawy albo jakieś niewyszukane danie), ale $\mathrm{w}$ gościnie ważne jest spotkanie $\mathrm{z}$ drugim człowiekiem. Okoliczności te ujawniają pewien paradoks - to kobiety zazwyczaj pilnują trwałości tradycyjnych wzorców goszczenia, choć właśnie dla nich jest to najbardziej obciążające. Jak zatem wytłumaczyć fakt, że wpędzają się same w tę ze wszech miar wyczerpującą sytuację? Rancew-Sikora i Żadkowska (2017, s. 81) wyjaśniają, iż przywiązywanie tak wielkiej wagi do przygotowania przyjęć jest spowodowane tym, że kobiety są bardzo wrażliwe na opinie gości, na to, jak zostaną ocenione, jak wypadną w ich oczach. Również u badanych przez nas respondentek można było zauważyć tego rodzaju motywację. Nawet wykształcone, autorefleksyjne kobiety przyznawały, że chociaż przede wszystkim zależy im na dobrej atmosferze i rozmowach podczas spotkania z gośćmi, to ogromną wagę przywiązują też do aprobaty dla ich umiejętności kulinarnych. Cieszy je/smuci (a czasem nawet krępuje) to, jak poradziły sobie w kuchni. Tak żywe emocje związane z oceną talentów kulinarnych gospodyni, wyrażane przez sporą część respondentek, pokazują, że mimo nowych możliwości (takich jak catering, coraz szersza oferta artykułów gotowych, przyjmowanie gości w lokalu itp.) samodzielne zastawienie stołu dla wielu nadal jest istotnym obowiązkiem kulturowym i miarą gościnności.

B: A co Pani lubi w przyjmowaniu gości? Co sprawia tę przyjemność, że...? R: Wie Pani co, że jak ugotuję i oni jedzą! [śmiech] No tak sobie myślę.

B: Ale wystarczy, że jedzą, czy jeszcze muszą chwalić?

R: Nie, chwalić nie musza, wystarczy, że tego, że... nie lubię jak mi jedzenie zostaje. No wtaśnie chyba też klimat, atmosferę. Czy sa wspólne tematy, czy rozmowy się kleja, o czym rozmawiam, jak czas mija, tak. [K,40,wyższe]

B: Co najbardziej lubisz w przyjmowaniu gości? Mówisz, że taki gwar, że coś się dzieje? Mówiłaś coś takiego?

R: Tak. Takie bycie i rozmowy. Że można sobie pogadać po prostu. Ale no może trochę mnie stresuje, bo ja naprawdę się nie czuję gospodyniq. I nie upiekę, nie usmaże, nie zrobię takich rzeczy. I myślę, że jak zrobię to niekoniecznie będzie smakowało. [K,34,wyższe]

Skrępowanie niewypełnianiem lub nawet tylko częściowym niedopełnianiem wszystkich wymagań kulturowych związanych z rolą gospodyni 
i wpędzanie się w tę trudną i wyczerpującą rolę można wytłumaczyć przez odwołanie do dobrze znanej koncepcji habitusu (Bourdieu 2004). Okazuje się bowiem, że pewne przekonania na temat tego, jak należy przyjmować gości, zostały tak głęboko ucieleśnione, że trudno się od nich wyzwolić, nawet jeśli na poziomie świadomości dostrzega się ich nieracjonalność i mankamenty.

Przedstawione do tej pory wypowiedzi pokazywały, że wzór kobiecej transmisji pokoleniowej dotyczącej gościny wpisuje się $\mathrm{w}$ proces socjalizacji oparty na modelowaniu społecznym. Jednak relacje matek z córkami są o wiele bardziej skomplikowane i (przynajmniej współcześnie) rzadko opierają się na prostym powielaniu wzorców i zachowań starszego pokolenia. Elżbieta Korolczuk (2019) wskazuje, że do wyjaśniania przemian zachodzących $\mathrm{w}$ relacjach między różnymi pokoleniami kobiet znacznie bardziej użyteczny - mimo pewnych wad, takich jak nadmierne uproszczenie czy zbytni optymizm - jest międzygeneracyjny model przemian kobiecej tożsamości autorstwa Harriet Bjerrum Nielsen i Monicy Rudberg (1993; por. Korolczuk 2019, s. 98-104). Proponują one, by uwzględniać rozróżnienie na: „tożsamość płciową” (czyli zestaw zasad i ról, które trzeba odgrywać, by zostać zrozumianym i zaakceptowanym w danej rzeczywistości społecznej), „upłciowioną podmiotowość” (czyli uwewnętrzniony wymiar płci, postrzeganie przez jednostkę tego, jak być kobietą/mężczyzną) i kulturowo-społeczne warunki (realne możliwości dostępne w danym miejscu i czasie). Rozróżnienie to pozwala zrozumieć niespójności między obecnie często szybciej zmieniającym się społecznie akceptowanym wzorem tożsamości płciowej (np. kobiety i mężczyźni w partnerski sposób dzielą się obowiązkami kuchennymi) a bardziej stabilną i trudniejszą do zmiany - bo tworzoną przez jednostkę od czasów procesu socjalizacji pierwotnej - upłciowioną podmiotowością (np. przekonanie kobiet, że to przez zapewnienie dobrej jakości i dużej ilości pożywienia wyraża się troskę i opiekę).

O trafności takiego podejścia także w odniesieniu do praktyk goszczenia mogą świadczyć wypowiedzi badanych, w których ujawniały się pewne zgrzyty, komplikacje lub nawet próby zerwania ze wzorami gościnności praktykowanymi przez rodzicielki. Jedna $z$ młodych respondentek wielokrotnie podkreślała, że denerwuje ją praktykowany przez jej mamę i tatę model gościnności, który postrzegała jako nadmierne nadskakiwanie osobom, które przybyły z wizytą. Przyznawała jednak, że chociaż zetknęła się z bardziej swobodnym podejściem rówieśników, nie potrafi się od niego wyzwolić („mi to tak głęboko w mózg weszło”). Podobne były odczucia starszej badanej, która opisywała, jak niezdrowe i nieracjonalne jest 
przygotowywanie zbyt dużej ilości jedzenia, a następnie biła się w piersi, przyznając, że sama tak robi, bo wzoruje się na swojej matce. Obydwa przytoczone przykłady pokazują, że akceptacja nowego wzorca i możliwości jego realizacji były niespójne $z$ upłciowioną podmiotowością, co czasem wywoływało poczucie frustracji.

A tu czułam się swobodnie. Momentami nawet dziwnie, jak chciałam sobie zrobić śniadanie to [imię koleżanki] powiedziała: idź sobie zrób. A u mnie w domu byto tak, że moja mama by tam napierdzielała $w$ garnkach. Takie ustugiwanie. [...] Jak ja kogoś goszczę, to nie mówię: „idź sobie, weź”, tylko mu daję. Tak mam z domu, że jak jest gość, to masz mu zapewnić maksymalny komfort pod każdym katem. [...] Ale to też wynika $z$ tego mojego domu. Bo goście to problem. I mi to tak głęboko w mózg weszło, że też tak myśle, że gość to problem. Dlatego ja świruję. [K,28,wyższe]

[o wizytach u przyjaciółki] Oni też robia dużo więcej potraw. Ja po pierwsze staram się nigdy nie jeść dużo. Męczy mnie taka zbyt duża ilość potraw! Ja sama też tak robię, ale u siebie tego nie widzę! [...] ja kiedyś szykowatam znacznie więcej! Moja mama też...Ja bardzo lubię przyjmować, ale gorzej się czujęjako gość. [K,60+,wyższe]

O tym, jak trudno jest zmienić istniejący od pokoleń w danej rodzinie wzorzec gościnności, świadczyły też wypowiedzi, w których podkreślano, że córki często na poziomie deklaracji i racjonalnej oceny oraz świadomości ponoszonego wysiłku byłyby gotowe na zmiany. Jednak zasada wzajemności obowiązująca $\mathrm{w}$ danej rodzinie czy konflikt $z$ innymi ważnymi wartościami, takimi jak szacunek dla starszych (co można by w świetle przytoczonego wcześniej modelu Bjerrum Nielsen i Rudberg interpretować jako brak możliwości/warunków), powodowały, że na poziomie praktyk nic się nie zmieniało.

Jeżeli chodzi o moja rodzine, to moja mama jest taka, że nawet nie chce pomocy, jak przygotowuje. A jak tutaj przyjeżdża na gotowe, to nawet żatuje, że nie zapyta, czy nie upiec ciasta. Jak ona robi coś u siebie, to bierze wszystko sama na głowę i nawet nie oczekuje pomocy. Jak ja się jej pytam, to ona jest zdziwiona, że przecież wszystko będzie zrobione. Ona tak to rozumie, więc jak przyjeżdża, to dokładnie $w$ taki sam sposób. [K,ok.40,wyższe]

Tak, moja mama była bardzo otwarta i towarzyska. Ale muszę Pani powiedzieć, że już mam inny charakter niż moja mamusia. Mi się to nie zawsze podobało.

B: A kiedy się Pani nie podobało?

R: Za dużo miałam tych mamy koleżanek, które musiałam obstugiwać.

B: Obsługiwać?

R: No tak, ale jak przyszła taka babcinka do babcinki, to kto musiał obstugiwać? No ja. $[\mathrm{K}, 50+$,wyższe $]$ 
Wreszcie kolejne wyjaśnienie (obok wrażliwości kobiet na oceny innych, oddziaływania habitusu czy międzygeneracyjnego modelu przemian kobiecej tożsamości), które warto wziąć pod uwagę przy interpretacji niespójności i opisywanych w cytowanych wypowiedziach konfliktów wewnętrznych przeżywanych przez respondentki, pochodzi z koncepcji Jeana-Claude'a Kaufmanna (2004). W przeciwieństwie do przytaczanego wcześniej modelu Bjerrum Nielsen i Rudberg skupia się on na poziomie jednostki. Wychodzi też z założenia, że sformułowana przez Bourdieu definicja habitusu ma wiele zalet, ale i pewne wady, między innymi nie pozwala ująć wszystkich sposobów rejestrowania pamięci ukrytej. Kaufmann (2004, s. 149-150) kluczowe znaczenie przypisuje przyzwyczajeniom, które określa jako wcielone schematy operacyjne. Na podstawie badań dotyczących w dużej mierze prac domowych, między innymi gotowania, prania, sprzątania (zob. Schmidt 2010; Żadkowska 2012), stworzył on koncepcję uwzględniającą zarówno ucieleśnione rutyny, jak i refleksyjność, a mówiąc inaczej: zarówno wcieloną przeszłość (jak w przypadku habitusu), jak i czynne dostosowywanie się do teraźniejszości. Wiele uwagi poświęcił przy tym dysonansom, niespójnościom, zderzaniu się ze sobą tych dwóch sił. To konflikty między rywalizującymi schematami operacyjnymi wywołują refleksyjność i wywierają presję na jednostkę, by rozpocząć interioryzację. Dokładnie taki proces obrazują przytaczane wyżej rozterki respondentek, chcących wyzwolić się - na razie bez wielkich sukcesów - $z$ nawyków wpojonych im przez matki (potwierdzając jednocześnie ustalenia Kaufmanna, że jest on zwykle długi, a jego wynik niepewny, co oznacza, że na kontinuum od niemal pełnej refleksyjności do niemal pełnego zautomatyzowania nadal pozostaje daleki od cielesnej inkorporacji). Mają one świadomość, że istnieją inne schematy działania (np. dawanie większej swobody gościom, mniej sute zastawienie stołu), jednak ucieleśnione $\mathrm{w}$ procesie wczesnej socjalizacji rutyny nadal nie pozwalają im na łatwą zmianę tego wyczerpującego i frustrującego wzorca gościnności.

\section{ON, ONA I ONE W KUCHNI}

Można zadać pytanie, dlaczego tak wiele miejsca poświęcam kwestiom planowania i przygotowywań na przyjście gości, podkreślając przy tym paradoksalność trwania wielu kobiet przy standardach „uginających się stołów”, uznawanych za charakterystyczne dla kultury polskiej. Podczas analizy transkrypcji wywiadów uderzające było to, że mimo wielu innych zmian opisywanych przez respondentów (zwłaszcza starszych, na przykład częstości i pretekstów do spotkań towarzyskich, 
zapraszanego grona gości, mniejszej ilości alkoholu na stole niż dawniej ${ }^{5}$, mód kulinarnych itp.) przemiany w tym zakresie również zachodziły, ale — jak się wydaje - zaskakująco wolno w porównaniu $z$ innymi. W przeważającej części badanych rodzin za mniej lub bardziej „naturalne” uznawano, że to kobieta jest odpowiedzialna za większość przygotowań związanych z przyjmowaniem gości, a mężczyzna — czyli gospodarz — jej w tym „pomaga” (to określenie zwykle pojawiało się w wywiadach, jasno wskazując, kto ponosi główną odpowiedzialność) ${ }^{6}$. W zależności od tradycji i modelu podziału obowiązków panującego $\mathrm{w}$ danym domu owa pomoc obejmowała szerszy lub węższy zakres czynności, takich jak zaproszenie gości, nakrycie stołu, zorganizowanie wystarczającej liczby krzeseł, zaopatrzenie w niezbędne produkty (zwłaszcza alkoholowe, co często uznawano za wyłącznie męską „strefę wpływów”) czy sprzątanie. Jeśli jako pomoc opisywano obecność panów w kuchni (co samo w sobie było już znacznie rzadsze - warto zwrócić uwagę, że wszystkie wymienione czynności związane były z przestrzeniami pozakuchennymi lub nawet pozadomowy$\mathrm{mi}$ ), to zwykle była ona drugoplanowa lub dość wycinkowa, ograniczała się na przykład do zmywania, obierania ziemniaków, krojenia warzyw na sałatkę czy, sporadycznie, przygotowania popisowego dania: mięsa lub deseru.

Choć trudno na podstawie jednorazowo zebranych danych jakościowych wysnuwać wnioski o przemianach wzorców gościnności, porównanie wypowiedzi respondentów wskazywało, że największe różnice w tym zakresie były związane $z$ wiekiem i kapitałem kulturowym badanych. Starsi rozmówcy — niezależnie od posiadanego wykształcenia - stosowali się zwykle, co zrozumiałe, do bardziej tradycyjnego płciowego podziału obowiązków. Kobiety brały na siebie zdecydowaną większość kwestii związanych z przygotowaniami do przyjścia gości (a czasem niemal wszystkie) i zwykle uznawały to za oczywiste. Zaznaczały nawet że to właśnie one nie dopuszczają swoich partnerów „do garnków”. Wydaje się, że gotowanie i żywienie innych stało się dla nich, tak samo jak dla respondentek

${ }^{5}$ Co oczywiście nie oznacza, że obecnie nie ma alkoholu na stołach. Respondenci, zwłaszcza mężczyźni, z aprobatą wspominali o tym, jak „woda rozmowna” rozluźnia atmosferę gościnnych przyjęć. W odczuciu badanych zmieniła się jednak nie tylko ilość (coraz rzadsze przypadki upicia się, nawet podczas dużych rodzinnych imprez, takich jak wesele), ale i jakość podawanych trunków (coraz częściej na stołach pojawiają się alkohole gatunkowe, wina, piwa, kolorowe drinki, zamiast wódki czy popularnego dawniej bimbru).

${ }^{6}$ Analogiczny wniosek wysnuwa Anne Murcott (1983a) z badań nad podziałem obowiązków związanych z przygotowywaniem codziennych domowych posiłków w południowej Walii w latach osiemdziesiątych XX wieku. 
z badań Murcott (1983b, s. 179), ważnym społecznym środkiem produkowania i reprodukowania płci kulturowej.

[...] przed tymi imprezami to żona już od środy z kuchni nie wychodzi [śmiech]. Szykuje jedzenie! Tylko żona ma taki zwyczaj, że ona naszykuje. I tych sałatek! Tego wszystkiego! No mnóstwo tego jedzenia. I jak przyjda goście to od razu na stót wszystko postawi $i$ siada, z gośćmi siedzi, nie? [...] To znaczy moim zadaniem jest, wie Pani, zrobić porzadek $w$ tym pokoju, gdzie będzie przyjęcie. Stót nakryć, przygotować wszystkie naczynia, tzn. tam talerzyki, noże, widelce, to wszystko... No tam córka mnie nieraz wyręczy, nie? Ale tak to zawsze... i później krzesła trzeba też uszykować, bo wszystkie krzesła nie mamy tam... mamy na strychu, to trzeba poznosić, poukładać, poustawiać. [M,75,średnie]

B: Proszę mi powiedzieć co Pan lubi w przyjmowaniu gości? Co jest takiego co sprawia przyjemność $\mathrm{w}$ przyjmowaniu gości u siebie?

R: Czym tu gości zaskoczyć! [...]

B: I jak Pan zaskakuje swoich gości?

R: Najczęściej to żona upiecze coś, jakiś nowy pomyst, a ja otwieram drzwi i wprowadzam gości [śmiech]. [M,70+,wyższe]

R: To znaczy się maż mi bardzo dużo pomaga przy nakrywaniu. Podaje. Czy tam coś, ktoś potrzebuje. I później mi pomaga, zbiera naczynia czy myje. Pomaga mi.

B: A Pani zajmuje się gotowaniem zazwyczaj?

R: Tak, tak. Bo ja lubię sama. Tam nieraz mówię: zamieszaj, czy coś, nie, tego. Ale pomaga mi później pozbierać po gościach, czy ja zbieram, on stoi i myje. Bo ja nie mam zmywarki. To stoi i myje. Tak, że pomaga mi. [K,64,zawodowe]

Wyniki badań z zakresu socjologii par (Żadkowska 2016; Schmidt 2015) pokazują, że w pokoleniu dwudziesto-, trzydziesto-, a nawet czterdziestolatków przekonania i realnie wdrożone modele podziału codziennych obowiązków (w tym przygotowywania posiłków) bardzo znacząco się różnią, między innymi w zależności od tego, czy partnerzy mają dzieci (co ciekawe, nawet jeżeli w związku dzielono się obowiązkami kulinarnymi, to te związane $z$ dzieckiem przejmowała kobieta; zob. Żadkowska 2016, s. 122-148). W przedstawianych tu badaniach nad gościnnością również zaobserwowano wiele różnic wśród respondentów z młodszej kategorii wiekowej - pojawiały się one przede wszystkim w zależności od kapitału kulturowego partnerów i środowiska, w którym się obracali. Tradycyjny podział obowiązków związanych z przygotowywaniem potraw zdarzał się także w przypadku młodych osób z dyplomem szkoły wyższej, jednak w tym gronie stosunkowo częściej podawano przykłady mężczyzn (respondentów i ich rodzin lub znajomych), którzy specjalizują się w pieczeniu mięs czy ciast, potrafią poradzić sobie w kuchni, a nawet takich, dla których gotowanie jest pasją. Być może przekonanie, że od strony ku- 
linarnej przyjęcie dla gości szykuje ta osoba, która akurat ma więcej czasu lub jest bardziej zainteresowana kulinariami (niezależnie od płci), można traktować jako prognostyk przyszłych przemian. Na razie jednak model ten podawany był raczej jako ciekawostka, pretekst do wyróżnienia i pochwalenia (siebie/męża/znajomego itp.) ${ }^{7}$.

Mój maż lubi kuchnię i lubi gotować. Lubi też serwować dziczyznę, więc dla niego też jest to pole do popisu. Lubi to przygotowywać, w szczególności jak jest to dla ludzi, którzy są otwarci i nie maja tego na co dzień, uciesza się, mogąc czegoś skosztować. [K,ok.40,wyższe]

[...] mąż tė̇ potrafi $w$ kuchni działać, więc mam ten plus, że wie co do czego. Jak trzeba, to i przygotuje mięso i cała resztę. Jak mnie nie ma, to też ze wszystkim sobie poradzi. [K,ok.40,wyższe]

O na przykład przyjaciótki maż, no, no [imię] najbardziej też lubi gotować. I oni raczej tak wola nas zostawić w kuchni, nie. No tak jak jest jakieś tam gotowanie takie wspólne, no, bo oni rzeczywiście mają dom... Kuchnię, zazdroszczę. No po prostu [imię] jest $w$ ogóle architektem $i$ to gotowanie jest jego pasja, więc zaprojektowat to tak, że, że ta kuchnia takim centrum [...]. [K,38,wyższe]

Co ciekawe, pojawiły się opowieści o panach, którzy odpowiedzialni byli za przygotowanie mięs, partnerkom pozostawiając szykowanie dodatków (zwłaszcza sałatek, surówek itp.). Na szeroką skalę ujawniało się to zwłaszcza w opisach grillów organizowanych dla rodziny i znajomych (nawet wśród starszych respondentów, opisywanych wcześniej jako praktycy bardzo tradycyjnego podziału obowiązków płciowych podczas przyjęć domowych, to zazwyczaj mężczyźni sprawowali nadzór nad rozpaleniem grilla i przygotowywanymi mięsami).

W przygotowaniach to sama uczestniczę, bo mą̇ mówi: „Ja mam dwie lewe ręce, to ci w niczym nie pomoge", ale jak tylko przychodzi ciepto i siedzimy na dworze, wykorzystujemy wtedy każdą chwile [robimy wtedy grille], wtedy to już jest broszka mojego męża. Ja wtedy robie sałatki, a on mięso. [K,44,średnie]

Podział na „męskie” mięso i „kobiece” warzywa jest bardzo bliski opozycjom opisywanym przez Bourdieu (2005, s. 237-243) (m.in. delikatne-pożywne) na podstawie badań przeprowadzonych we Francji lat siedemdziesiątych. Jego zdaniem u podstaw społecznego definiowania pokarmów „stosownych” dla określonej płci leżały przekonania dotyczące ciała — jego

\footnotetext{
${ }^{7}$ Powszechnie panowało jednak przekonanie, że to kobieta bierze na siebie obowiązek przygotowywania potraw dla gości, nawet gdy tego nie lubi: W zależności od tego, czy jest to uprzedzona wizyta, czy nie, to zazwyczaj jakieś ciasto na szybko. Jak dłuższa wizyta to coś gotuję. Nie lubie gotować [śmiech], no ale trzeba... Jak trzeba to trzeba. [K,39,wyższe]
} 
wyglądu („męskiej” siły lub „kobiecej” szczupłości), a także sposobu używania go podczas jedzenia (stąd na przykład przekonanie o tym, że jedzenie ryb i obieranie ich z ości jest „niemęskie”). Inną interpretację zainteresowania mężczyzn grillowaniem mięsa przedstawia Kaufmann (2007, s. 73). Omawiając wnioski z jego badań, Żadkowska (2012, s. 145) zauważa:

„Kobiety i mężczyźni nie różnią się w kuchni, bo tak chce biologia, bo pochodzą z dwóch różnych planet. Różnią się, bo czym innym w procesie socjalizacji stała się dla nich kuchnia. [...] Mężczyźni strzegą z zazdrością atawistycznego zainteresowania ogniem i pieczonym, grillowanym mięsem, pochodzącego z zamierzchłych czasów, gdy byli myśliwymi [...]. Dlatego bliżej im do grilla niż do kuchenki. W kuchni czują się nieporadni, najchętniej z niej uciekają".

W młodszych pokoleniach stosunkowo częściej szerszy był także zakres męskich obowiązków pozakuchennych związanych z imprezami rodzinnymi i towarzyskimi: panowie angażowali się bardziej w sprzątanie czy przygotowywanie atrakcji dla dzieci (jeśli była mowa o imprezach dziecięcych). Mimo wszystko jednak w wywiadach kwestie dotyczące porządku bardziej podkreślały niemal wyłącznie kobiety. Część obawiała się krytycznych uwag w przypadku bałaganu w domu, a niektóre były zawstydzone i przepraszały niejako „na wyrost”, nawet gdy groźba niezapewnienia gościom wystarczającego standardu czystości pojawiała się tylko hipotetycznie, w ich mniemaniu (bezpośrednio doświadczyli tego także badacze i badaczki AbnŻC, przeprowadzając wywiady w domach). Naświetla to kolejny interesujący problem, który ponownie można interpretować w kategoriach trwałości habitusu, niespójności między tożsamością płciową a upłciowioną podmiotowością albo Kaufmannowskich „pułapek” 8 i sprzeczności przyzwyczajeń w wyniku konfrontacji różnych scenariuszy działania (por. Schmidt 2010, s. 61-62). Okazuje się bowiem, że nawet jeśli zachodzi zmiana na poziomie praktyk i mężczyźni bardziej angażują się $\mathrm{w}$ prace porządkowe, to ucieleśnione przeświadczenie o tym, że to jednak kobieta jest odpowiedzialna za czystość domu, u części respondentek powoduje „kulturowy wstyd" wynikający z niesprostania temu obowiązkowi.

R2: Wtaśnie ci najbliżsi, rodzina i przyjaciele - nie czujemy się skrępowani, gdy oni wchodza. Często z nimi posprzątamy, prasowanie, chowanie - zabawki. Nie czujemy skrępowania żadnego.

\footnotetext{
${ }^{8}$ Mianem pułapek Kaufmann (1995) określa sytuacje, w których kobiety jednocześnie odgrywają sprzeczne role: tradycyjne i egalitarne, co przejawia się na przykład w tym, że nie mogą zarzucić obowiązków domowych, choć wcale nie chciałyby ich wykonywać (zob. Żadkowska 2016, s. 248).
} 
R1: To znaczy mą̇̇ nie czuje, ja czuję duże [śmiech]. [MiK,30+,wyższe]

Kolejne dowody na to, że mimo symptomów pewnych zmian goszczenie jako sprawowanie opieki nadal w dużej mierze spoczywa na kobietach, można odnaleźć w sferze pomocy gospodarzom w przygotowaniach. Analiza wypowiedzi pokazała, że oprócz pani i pana domu w prace często angażowane są również ich dzieci. Co ciekawe, w przypadku dzieci, które nadal mieszkały z rodzicami (a więc w zdecydowanej większości osób należących do najmłodszego pokolenia), mówiono zarówno o córkach, jak i synach (choć niekiedy ujawniały się dysproporcje w ich obowiązkach). Co ważne, respondenci ci reprezentowali różne środowiska społeczne. Także dorosłe córki, nie mieszkające już z rodzicami, pomagały im w sytuacji gościny.

No, syn przeważnie ma tak: jeżeli jest sernik, to syn mieli ser. Koniecznie. Ciasta należą do niej [pokazuje na starszą córkę], bo biszkopty ma takie! [...] Do kremów jak ona jest zajęta, to jemu daję. No co to jemu szkodzi stać i tylko mikser. On siedzi, bajki ogląda czy tam filmy, a ja będę stała. I to, i to. On stoi z mikserem na przykład to masę mi tam zrobi jedna. Do niego na przykład należy mielenie mięsa czy posiekanie kapusty... [K,42,zawodowe]

Teraz maluchy potrafia do stołu przyszykować, więc to jest fajne. Nosza naczynia i sztućce, to co moga, i ustawiaja. [K,ok.40,wyższe]

Mama stoi w kuchni, a my szykujemy do stołu. Talerze rozstawiamy... Dużo też angażujemy dzieci, żeby pomagaty. Mama nas tak właśnie wychowała, że ona wszystko musi sama zrobić. [...] W bloku są mate kuchnie, więc na nas trzy, to już jest za mało miejsca. Dzielimy się tak, że mama $w$ kuchni, a my rozdzielamy na pótmiski, znosimy rzeczy. Już jest taki przydziat. Moja siostra, jak sa święta, to ona stoi w kuchni przy krokietach i ma swoje zadanie. Ja na przykład stoję i mieszam kapustę, żeby sięnie przypaliła. Teraz już powoli nas dopuszcza do tych garnków [śmiech]. [K,38,średnie]

Do drugiej grupy „pomocników” należały kobiety-goście, zazwyczaj te, z którymi relacje gospodarzy były szczególnie bliskie. Zdarzały się przypadki „samopomocy kobiecej”, gdy matki, teściowe czy siostry proszone były o przygotowanie na imprezę rodzinną jakiegoś jednego dania czy deseru, którego gospodarze nie zdążyliby/nie umieliby tak dobrze przyrządzić, na przykład tortu (mowa oczywiście o przyjęciach, które nie miały charakteru składkowego). Opisywano też sytuacje, w których kobiety-goście spontanicznie proponowały pomoc, zwykle $\mathrm{w}$ takim zakresie, $\mathrm{w}$ jakim $\mathrm{w}$ wielu innych przypadkach zajmowali się tym domownicy płci męskiej, a więc na przykład przy zanoszeniu potraw na stół czy zmywaniu. Działania takie odciążały zatem bardziej gospodarza niż gospodynię. Mimo wszystko jednak panie chwaliły sobie zwykle takie rozwiązanie, zyskiwały bowiem możliwość umilenia dość żmudnych obowiązków rozmową i wspólnymi żartami. 
A tam już wtaśnie kuzynka czy kuzynów żony, przecież to, to kuzyn, a obce kobiety, to tak zwane przy rodzinie [śmiech], prawda? No. Inaczej myśla po prostu. Inaczej myśla. No wstanę, pomogę, no, bo, no, bo wiadomo, nie. Jest dużo pracy i, i ciasnota przede wszystkim, no to my tam sobie nieraz po obiedzie, chłopy tam po piwku, kobiety poszty, jedna drugiej pomoże. Swoje tematy maja kobiety. No, o różnych sprawach rozmawiaja. I, $i$, i to mi się tak podoba. Taka pomoc, nie. [M,56,średnie]

Ja przygotowuje $w$ kuchni potrawy, a mam taki aneks kuchenny. I jakjuż mam wszystko gotowe, stawiam na blat i mój maż po prostu nosi. Nosi. A ja ewentualnie jak coś mi sie nie podoba, wiesz jak to baba [śmiech], to po prostu przestawiam po swojemu, nie. Ale też bytoby to fajne, i chyba tak kiedyś tak byto... [...] mojego syna chrzestna, wyjechała do Stargardu. Ale pochodzi $z$ [nazwa miejscowości] $i$ bardzo często się spotykatyśmy, dopóki nie wyjechała. Więc też wspólnie razem w kuchni żeśmy sobie tam coś kroity, razem. Po prostu razem. Gadatyśmy, śmiałyśmy się i tam kroity... Kroityśmy sałatkę, tak. Tak, że byto wspólne przygotowanie positków. Byto. $[\mathrm{K}, 37$, wyższe $]$

Warto zauważyć, że w przytoczonych wypowiedziach kolejny raz uwidacznia się pewna sprzeczność: $z$ jednej strony podkreślenie, że kuchenne przygotowania do przyjęcia gości są dość wyczerpujące i pomoc jest mile widziana, z drugiej jednak kobiety czasem same nie dopuszczają lub krytycznie podchodzą do oferowanej im pomocy, zwłaszcza męskiej. Grono gospodyń, które w ogóle nie chciały dopuszczenia gości do „zakulisowej” (zob. Goffman 1981) strefy kuchennej (czasem powołując się na wzór matek podkreślały, że nawet talerze i sztućce wolą znieść ze stołu same), było całkiem spore, pewna część badanych gotowa była jednak zrobić wyjątek dla wybranych pań, tworzyły tym samym w kuchni specyficzną „kobiecą strefę”. Podobne zachowania swoistego „wyrzucania mężczyzn z kuchni”, choć w sytuacjach codziennych, niezwiązanych z gośćmi, zauważył Kaufmann $\mathrm{i}$ interpretował je jako trudność $\mathrm{w}$ rezygnacji $\mathrm{z}$ kobiecej władzy tam sprawowanej (por. Żadkowska 2012, s. 145).

\section{DOMOWA TOWARZYSKOŚĆ KOBIET I „POKĄTNE” SPOTKANIA MĘŻCZYZN}

Opisane praktyki, w których mimo pewnych wyjątków kobiety w większości sprawują kontrolę nad materialnym/infrastrukturalnym aspektem przyjmowania gości (to one zwykle ostatecznie decydują o tym, co i w jaki sposób zostanie zaserwowane, a także gdzie i w jakich warunkach w wymiarze porządku), mają określone konsekwencje. W przeprowadzonych badaniach najbardziej uwidoczniła się kwestia różnic w sposobach traktowania mieszkania przez kobiety i mężczyzn. 
W literaturze sporo uwagi poświęcono opisowi procesu feminizacji domu w kulturach zachodnich, który zachodził od XVII wieku (Rybczyński 1996). Badacze podkreślają, że podział na „kobiecą” przestrzeń prywatną i „męską” przestrzeń publiczną najbardziej sztywny był w społeczeństwie wiktoriańskim w warstwie średniej (Skowrońska 2015), ale pewne jego elementy utrzymują się do dziś w Polsce i innych krajach, nie mówiąc o społecznościach muzułmańskich (zob. Bourdieu 2007; por. m.in. Chruścińska 2009; Cebula 2015). Pisarek (2016, s. 77-78) zauważa, że dawne, tradycyjne polskie schematy „gościnności pieca” i „gościnności stołu”, które $\mathrm{w}$ zależności od kontekstu łączono $\mathrm{z}$ dychotomią kobiece-męskie czy codzienne-świąteczne, niezwykle trwale zapisały się w zbiorowej wyobraźni. W miarę zmiany przestrzennego układu izb mieszkalnych oraz wzorów ich wyposażania uległy one tak niewielkiej transformacji, że współcześnie nadal możemy mówić (mimo pewnych zastrzeżeń) o powiązaniu kuchni z „gościnnością kobiecą" i salonu z bardziej oficjalną „gościnnością męską”. Również przytaczane przez Davida Morleya (2011, s. 90-93) anglosaskie badania pokazywały, jak istotne symboliczne znaczenie pod koniec XX wieku przypisywano nadal przygotowaniu przez gospodynię wystawnego obiadu świątecznego dla krewnych oraz $\mathrm{w}$ jakim stopniu kuchnia oraz sprzęty gospodarstwa domowego były jej „strefą wpływów” (np. w badaniach Pauline Hunt z 1989 roku respondentki odpowiadały, że „ich pokojem”, ich przestrzenią jest kuchnia bądź po prostu cały dom jako taki, a studium Mary Bouquet - przeprowadzone na angielskich farmach w 1986 roku - dowodziło, że budynki gospodarcze nadal traktowano jako strefę „męską", a mieszkalne - „kobiecą” [zob. Morley 2011, s. 02-93], podobnie jak w klasycznych badaniach Bourdieu nad społecznością Kabylów).

Mimo wielu przemian kulturowo-technologicznych zachodzących w ostatnich latach w Polsce (tj. poszerzenie oferty gotowych do spożycia produktów, dostępność sprzętów typu kuchenka mikrofalowa, upowszechnienie zwyczaju jadania poza domem) w wypowiedziach współcześnie badanych kobiet i mężczyzn nadal można wyłapać echa tradycyjnych wyobrażeń i praktyk znanych jeszcze ze społeczeństw tradycyjnych. Okazywało się bowiem, że w przestrzeni domowej spotykają się albo całe rodziny, albo kobiety (często z towarzyszącymi im dziećmi), a gdy mowa była o umawianiu się mężczyzn ze znajomymi, sąsiadami, kolegami z pracy (rzadziej: $z$ innymi męskimi członkami rodziny), były wskazywane miejsca takie jak: garaż, podwórko przed domem lub blokiem, płot, altanka, rynek, pub, miejsce pracy czy boisko sportowe. Wyjątek czyniono ewentualnie dla wspólnego męskiego oglądania transmisji sportowych, bywało, że zapraszano się wówczas do domów, choć czasem zaznaczano, 
że jest to pewnego rodzaju wyłom w codzienności (np. mistrzostwa świata w piłce nożnej jako święto) lub podkreślano, że wspólne oglądanie zwykle bardziej komfortowe jest w barze sportowym/pubie.

Zdarza się, że znajomi do męża podjeżdżają. Niestety. Ale do towarzystwa nawet pala papierosy. I przyjada po to tylko, by zapalić papierosy [śmiech]. Więc podjeżdża pod dom, dzwoni, „wyjdź” i tak stoja. I przez chwilęnawet porozmawiaja w tygodniu [śmiech]. [K,30-40,wyższe]

Kolega przychodzi - puka, wychodzi na spacer z psem, „wyjdź porozmawiamy” i idziemy na spacer na przykład. [M,30+,wyższe]

R: Mam tutaj nawet takiego kolege [...], ma tutaj kebab, jeden $z$ wielu jego interesów; często idę tam do niego do pracy, a przy okazji sobie posiedzieć i pogadać, ale nie na kebab. Idę, patrzę, jak jest, to siedzimy i gadamy z godzine, nieraz dwie.

B: A do domu czyjegoś, nie zrobiłby Pan tego samego?

R: Wolatbym nie... Wiem, że to różnie $w$ domu bywa, mógtby być nieporzadek, nieposprzatane. [M,ok.40,wyższe]

R: Na mecz to jak się umawiam, to ja się przeważnie umawiam z kolegami, to oni przychodza.

B: Ale do Pana do domu?

R: No rzadko. Mamy taki lokal, że chodzimy tam sobie posiedzieć, poogladać i pokrzyczeć albo u drugiego kumpla ma też taki tak, że możemy sobie w ciszy i spokoju. [M,48,średnie]

Kobiety natomiast jako niemal oczywiste traktowały to, że ze swoimi koleżankami i sąsiadkami będą spotykać się w domu (wymieniano tu czasem także kawiarnię czy plac zabaw). Bardzo często pojawiała się w wypowiedziach wizja „babskich ploteczek” przy kawie - za oczywiste respondentki uznawały, że idealną scenerią dla tego rodzaju rozmów jest właśnie zacisze domowe, w którym czuły się swobodnie. Mniejsza popularność kawiarni czy innych przestrzeni publicznych jako miejsc spotkań mogła wynikać $\mathrm{z}$ faktu, że badanie przeprowadzano w mniejszych miastach, a tam często narzekano na niewielką dostępność lokali ocenianych jako odpowiednio przyjazne. Zasadnicze znaczenie jednak ma prawdopodobnie poczucie komfortu, jakiego doświadczają respondentki we własnym domu, co świadczy o tym, że podział na kobiecą sferę prywatną i męską sferę publiczną cały czas tkwi w świadomości zbiorowej i odgrywa znaczącą rolę w codziennych praktykach. Swoboda odczuwana przez badane podczas odwiedzin w domach wynika, jak się wydaje, $z$ optymalnego dla wielu kobiet połączenia kontroli nad przestrzenią z bardziej codziennym (w porównaniu $\mathrm{z}$ wystawnymi przyjęciami dla całych rodzin czy liczniejszych grup znajomych) wymiarem tego rodzaju wizyt: częstowano się wówczas raczej kawą i czymś słodkim, ewentualnie obiadem, co 
nie wymagało dużych nakładów pracy i pieniędzy, często też któraś z kobiet przynosiła na przykład ciasto.

Nie bez znaczenia jest też zapewne powiązanie gościnności kobiet $z$ cyklem ich życia - o domowych odwiedzinach często opowiadały panie, które na tego rodzaju spotkania zabierały dzieci, co zazwyczaj uznawały za rozwiązanie znacznie wygodniejsze i korzystniejsze niż konieczność szukania dla nich opieki czy pilnowania podczas rozmowy w kawiarni, zwłaszcza że alternatywę stanowiła całkowita rezygnacja $z$ życia towarzyskiego. W kilku wywiadach można było nawet zauważyć zwiększenie intensywności „domowej gościnności kobiecej” w okresie ciąży i urlopu macierzyńskiego, co tłumaczono nie tylko większą ilością czasu, ale i potrzebą wymiany informacji dotyczących wychowania dzieci (zwłaszcza co do wyboru spośród ogromnej oferty produktów i dostępnych usług) czy po prostu potrzebą kontaktu $\mathrm{z}$ innymi dorosłymi.

B: A co lubi Pani? Przygotowania, gościnę?

R: Sama gościnę, porozmawianie, jakieś babskie ploty. Uwielbiam spotykać się z moimi koleżankami, z którymi przez kilka lat pracowałam w opiece. Ja uwielbiam, jak one przychodza, aczkolwiek spotykamy sie, czy to u mnie, czy to u jednej, czy u drugiej... Raz na jakiś czas się wszystkie zmawiamy na jeden termin $i$ się spotykamy. Tam jakoś nie ma problemu — raz u jednej, raz u drugiej, raz u trzeciej... [K,30-40 ,wyższe]

[...] to byta jedna $z$ wielu wizyt po prostu moich koleżanek $z$ dziećmi. Po prostu przyszty, tam te dzieci się bawity, no to tak normalnie przebiega, jak to, wiadomo, jak to dziewczyny, plotki, ploteczki [śmiech], kawka, ciastka i tyle, nie? [śmiech] [K,20-30,studentka]

Odkąd sie pojawiła pierwsza córka — ja ja bardzo wcześnie urodziłam; miałam wtedy koleżanki, które też w moim wieku miaty dzieci. My się wtedy spotykatyśmy codziennie, miatam takie koleżanki, a teraz... [...], i na spacer się chodzito i do domu potrafityśmy iść do siebie, to byty takie całodniowe spotkania. A ja teraz tak siedze i myśle, że jak ja mogłam tak funkcjonować, nie wyobrażam sobie tego teraz. Wte$d y$, fakt faktem, nie pracowatam. Teraz sobie takich sytuacji nie wyobrażam. Praca, drugie dziecko, inne obowiązki przede wszystkim... [K,34,wyższe]

Również $\mathrm{w}$ wypowiedziach wielu starszych respondentów wyraźnie zarysowywał się kontrast między codziennymi odwiedzinami znajomych kobiet czy sąsiadek (w domach) i mężczyzn. Można było nawet odnieść wrażenie, że panowie, zwłaszcza starsi, są pozbawieni przestrzeni - nie czują się już swobodnie ani w pubach, ani w domach (gdzie spotykają się ich żony, a oni, przyjmując swoich kolegów, nie czuliby się tam gospodarzami). Zamieszczona poniżej wypowiedź dobrze obrazuje, jak męskie potrzeby (w tym również te dotyczące pogawędek o zwykłych, codzien- 
nych sprawach i przestrzeni niezbędnej do tego) łączą się z pewnym lekceważeniem czy protekcjonalnym pobłażaniem dla analogicznych potrzeb u kobiet (które jednak przynajmniej mają swoją przestrzeń na ich zaspokajanie).

My z kolega to sobie, o tak porozmawiamy, spotykajacc się. My nie idziemy na piwo jak nieraz mówią: „A muszę iść na piwo $z$ Władkiem”. Ja nie mam tego i nie umiem tego. I, i wiem, że on też nie [...]. Kiedyś byto inaczej, bo cztowiek byt mtodszy. To byty inne ciagoty, inne czasy. Pracowato się. Z pracy wyszli to tam tu poszli, wypili, tu poszli, wypili piwo. Nie ma tego, że my sobie idziemy gdzieś tam, wypijemy po dwa czy po trzy piwa, że my sie spotykamy na piwie. My sie spotykamy to tak sobie porozmawiamy koto domu, gdziekolwiek sie spotkamy: co tam u Ciebie? Jak tam w pracy? Tam on o sobie, ja o sobie. Bo, bo tajemnic żadnych nie mamy. I czy w ogóle, czy o rodzinie, co u mnie, co u moich dzieci, często pytają też, bo co, czy moja żona: co u niego? Bo maja dzieci, maja wnuki. I nie ma spotkań indywidualnych. Żony natomiast... Kobiety to kobiety. Maja swoje jakieś tam tematy, o swoich chorobach, o czymś tam jeszcze. Chca sobie, no maja swoje tematy [śmiech], to przy nas rozmawiaja o tym, to czasami, to my się i śmiejemy [śmiech]. A one sobie na poważnie tam coś poowijaja, poowijaja. No i sa szczesśliwe. Spotkaja się tam raz na dwa tygodnie na to... To tak do póttora godziny takie spotkanie. To nieraz moja mówi: Idę do Danki trochę, bo tam żeśmy rozmawiali, zaprosiła, żeby przyjš́c, nie. No. [M,56,średnie]

W kontekście wykluczenia symbolicznego mężczyzn w przestrzeni domowej (por. też Bourdieu 2007, s. $67^{9}$ ) warto też interpretować fenomen popularności grilla w Polsce. Ten rodzaj gościny sprawia, że mężczyźni stają się bardziej aktywni kulinarnie, gdyż czują się gospodarzami. Interpretując to zjawisko w kategoriach przestrzeni, można stwierdzić, że wynika to też $z$ tego, iż często na działce/w ogródku mężczyzna czuje się po prostu mniej skrępowany, „bardziej u siebie” niż w domu.

No wie Pan to, no nie mam, na przykład, tylu, tyle ziemi, ale te dwa ary tej dziateczki mam. I zdarzyto nam się, nam się też na działce zrobić takiego grilla rodzinnego, no to, to wtaśnie tam bytem gospodarzem. [...] No to tam człowiek, tam sie czutem gospodarzem. $[\mathrm{M}, 60+$,średnie]

\section{PODSUMOWANIE}

Omówione praktyki goszczenia zostały dobrane tak, by jak najlepiej pokazać, że zjawiska w sferze współczesnej polskiej gościnności rozpatrywane $z$ perspektywy płci kulturowej cechuje wiele paradoksów, niespój-

9 Bourdieu (2007, s. 167) zauważa: „stwierdzenie, że kobieta jest zamknięta w domu, jest zasadne tylko przy jednoczesnym zaznaczeniu, że mężczyzna jest z niego wykluczony, przynajmniej w ciągu dnia”. 
ności, a nawet sprzeczności. Gościnność uważa się za jeden z elementów powszechnie podzielanego przez Polaków autostereotypu, kobiety jednak są bardziej przywiązane do tej cechy. Dzieje się tak, mimo że - a może właśnie dlatego że - wymiar sprawowania opieki nad gościem właśnie na nie nakłada wiele wyczerpujących obowiązków. Pragną one pomocy $\mathrm{w}$ ich wypełnianiu, ale zarazem często ją odrzucają (zwłaszcza pomoc mężczyzn), jeśli nie spełnia ich wyśrubowanych standardów. Wzorują się bowiem na matkach, ciotkach i babkach, choć często - na poziomie racjonalnym - widzą minusy ich praktyk i wolałyby je zmienić. Zapełniają stoły obfitością potraw (zwykle samodzielnie przygotowanych), mimo że mają świadomość, jak wiele czasu, wysiłku i pieniędzy będzie je to kosztowało. Drżą o opinię gości w kwestii smaku dań i porządku, jednak wiele z nich trudno przekonać do przeniesienia spotkania do lokalu. Jak do rozwiązania tego mogą podchodzić mężczyźni, a jak kobiety, obrazują następujące wypowiedzi:

Tak już parę razy załatwitem, żona się zgodzita... jednak gospodynię to jest trudno namówić, żeby zrobić imieniny w lokalu. [...] $i$ te wszystkie zdenerwowania $z$ tym zwiazane. Kobieta to: „czy się wszystko uda, czy się nie uda”. Parę razy już zrobiliśmy w lokalu, tam jest osobna sala, te dwadzieścia parę osób bez kłopotu się pomieści. $[\mathrm{M}, 70+$, wyższe $]$

Często lubitem sam robić. To lubitem. Zresztą sita rzeczy potem każdy chwalit i lubitem przygotować coś swojego. [...] Tak mogę powiedzieć, że na przestrzeni czasu to się zmienito i to nie tylko u mnie $w$ domu, tylko $w$ ogóle. Kiedyś jak się spotykaliśmy, to wszystko byto przygotowane. Ja robitem zupe gulaszowa, spaghetti, jakieś sałatki, gyros i tak dalej. Już z czasem zaczęto to zanikać kosztem tego, że lepiej gdzieś pójść, catering zamówić nawet do domu. Cenowo, ekonomicznie, nie optacato się stać przy garach. [M,ok.40,wyższe]

Dążąc do teoretycznego wyjaśnienia opisywanych niespójności w praktykach kobiet, przywoływałam trzy teorie: (1) klasyczną koncepcję Bourdieu, choć jest ona krytykowana $z$ powodu pewnych problemów z opisywaniem dynamiki przemian habitusu; (2) wypracowany w toku studiów nad płcią model Bjerrum Nielsen i Rudberg, któremu zarzuca się jednak pewne uproszczenia i zbytni optymizm; (3) koncepcję Kaufmanna - popularną zwłaszcza wśród socjologów zajmujących się codziennością czy związkami intymnymi, między innymi dzięki satysfakcjonującym — również moim zdaniem - wyjaśnieniom powolnego tempa przemian podziału obowiązków domowych czy wręcz oporu wobec nich (zob. Schmidt 2010, s. 70) mimo deklaratywnego poparcia modelu partnerskiego (zob. Żadkowska 2016, s. 17-30). 
Przeprowadzona analiza pokazuje, iż role gospodarza oraz gospodyni w polskiej kulturze sytuują się niejako po przeciwnej stronie niż rola gościa (opisywana wyżej asymetria relacji), ale przy tym - jak dowodzi praktyka — osi podziału „my (gospodarze)-oni (goście)” niezwykle rzadko towarzyszy zniesienie wewnętrznego podziału: między gospodarzem i gospodynią. Choć omówione tu zostały jedynie wybrane praktyki, przywołano tylko kilka możliwych kontekstów teoretycznych i oczywiste jest, że potrzebne byłyby dalsze badania, zwłaszcza konfrontujące codzienne praktyki domowe i podział obowiązków $\mathrm{z}$ tymi realizowanymi $\mathrm{w}$ sytuacji pojawienia się gości, to można zaryzykować tezę, że praktyki związane z goszczeniem wręcz utwierdzają podziały płciowe, przypominają o nich, nawet jeśli na co dzień są one bardziej rozmyte. Można przypuszczać, że dzieje się tak, ponieważ genderowy podział obowiązków w sytuacji gościny zostaje wyraźniej odniesiony do sfery symboliki: wartości (w tym narodowych) i mitów (Matka-Polka). Ponadto okazuje się, że praktyki planowania i przygotowywania wizyty, często okupione wyczerpaniem gospodyń, niosą dla nich także pewne realne korzyści, w tym przede wszystkim poczucie utrzymania symbolicznej władzy nad przestrzenią domową. W świetle przeprowadzonych badań wydaje się, że właśnie to, nawet nieświadome, dążenie kobiet do zachowania monopolu na sprawowanie kontroli $\mathrm{w}$ przestrzeni prywatnej i czerpanie satysfakcji z uznawanego za należyte wypełnienia kulturowego obowiązku opieki nad gościem - to czynniki w najwyższym stopniu odpowiedzialne za wolne tempo zmian w kierunku bardziej partnerskiego i symetrycznego modelu gościnności.

\section{BIBLIOGRAFIA}

Bjerrum Nielsen Harriet, Rudberg Monica, 1993, Whatever Happened to Gender? Female Subjectivity and Change in a Generational Context, w: Janneke Van Mens-Verhulst, Karlein Schreurs, Liesbeth Woertman (red.), Daughtering and Mothering: Female Subjectivity Reanalysed, Routledge, London-New York.

Bourdieu Pierre, 2004, Męska dominacja, tłum. Lucyna Kopciewicz, Oficyna Naukowa, Warszawa.

Bourdieu Pierre, 2005, Dystynkcja. Społeczna krytyka władzy sądzenia, tłum. Piotr Biłos, Scholar, Warszawa.

Bourdieu Pierre, 2007, Szkic teorii praktyki poprzedzony trzema studiami na temat etnologii Kabylów, tłum. Wiesław Kroker, Wydawnictwo Marek Derewiecki, Kęty.

Brzozowska-Brywczyńska Maja, 2019, Akrobatyczny wymiar gościnności albo kilka uwag o tańcu na linie gościa z gospodarzem, w: Bogumiła Mateja-Jaworska, Marta Skowrońska (red.), Gość $w$ dom. Wspótczesne praktyki przyjmowania gości, Wydawnictwo Naukowe UAM, Poznań. 
Cebula Magdalena, 2015, Podziat przestrzeni w kulturze islamu, w: Alina Świeściak, Sandra Trela (red.), Strychy/piwnice: inne przestrzenie, Wydawnictwo Uniwersytetu Śląskiego, Katowice. Charmaz Kathy, 2009, Teoria ugruntowana. Praktyczny przewodnik po analiziejakościowej, Wydawnictwo Naukowe PWN, Warszawa.

Chruścińska Anna, 2009, W czterech ścianach. Zmiana znaczenia ról społecznych u Kabylów żyjacych we Francji, „Barbarzyńca”, nr 3-4, s. 59-67.

Cieśla Joanna, 2017, Sondaż POLITYKI: Jak Polacy postrzegają samych siebie?, „Polityka” (https:// www.polityka.pl/tygodnikpolityka/spoleczenstwo/1714316,1,sondaz-polityki-jak-pola cy-postrzegaja-samych-siebie.read [dostęp: 31.12.2019]).

Goffman Erving, 1981, Człowiek w teatrze życia codziennego, tłum. Helena Datner-Śpiewak, Paweł Śpiewak, Państwowy Instytut Wydawniczy, Warszawa.

Irigaray Lucy, 2016, Ku wzajemnej gościnności, „Opcje”, nr 3, s. 18-29.

Jakubowska Honorata, 2012, Trzymanie kobiet na dystans. Wykorzystywanie kategorii ptci, rasy i różnicy w profesjonalnym sporcie, „Kultura i Społeczeństwo”, nr 3, s. 75-94.

Jakubowska Honorata, 2013, Ptciowe porzadki - granice ptci $w$ sporcie wedtug koncepcji Mary Douglas, „Człowiek i Społeczeństwo”, t. 36, nr 1, s. 113-127.

Kaufmann Jean-Claude, 2004, Ego. Socjologia jednostki. Inna wizja człowieka i konstrukcji podmio$t u$, tłum. Krzysztof Wakar, Oficyna Naukowa, Warszawa.

Kaufmann Jean-Claude, 2007, Familles à table. Sous le regard de Jean-Claude Kaufmann, Armand Colin, Paris.

Korolczuk Elżbieta, 2019, Matki i córki we wspótczesnej Polsce, Universitas, Kraków.

Krajewski Marek, 2019, Stót, w: Bogumiła Mateja-Jaworska, Marta Skowrońska (red.), Gość $w$ dom. Wspótczesne praktyki przyjmowania gości, Wydawnictwo Naukowe UAM, Poznań.

Mateja-Jaworska Bogumiła, Marta Skowrońska (red.), 2019, Gość w dom. Wspótczesne praktyki przyjmowania gości, Wydawnictwo Naukowe UAM, Poznań.

Mateja-Jaworska Bogumiła, 2019, Gościnne Polaków rozmowy, w: Bogumiła Mateja-Jaworska, Marta Skowrońska (red.), Gość w dom. Wspótczesne praktyki przyjmowania gości, Wydawnictwo Naukowe UAM, Poznań.

McNulty Tracy, 2007, The Hostess: Hospitality, Femininity, and the Expropriation of Identity, University of Minnesota Press, Minneapolis-London.

Morley David, 2011, Przestrzenie domu. Media, mobilność i tożsamość, tłum. Jolanta Mach, Narodowe Centrum Kultury, Warszawa.

Murcott Anne, 1983a, "It's a pleasure to cook for him": Food, Mealtimes And Gender in Some South Wales Households, w: Eva Gamarnikow, David Morgan, June Purvis, Daphne Taylorson (red.), The Public and the Private, Hainemann, London.

Murcott Anne, 1983b, Cooking and the Cooked: A Note on the Domestic Preparation of Meals, w: Anne Murcott (red.), The Sociology of Food and Eating: Essays on the Sociological Significance of Food, Gower, Aldershot.

Pisarek Adam, 2016, Gościnność polska. O kulturowych konkretyzacjach idei, grupakulturalna.pl, Uniwersytet Śląski, Katowice.

Rancew-Sikora, Dorota, Żadkowska Magdalena, 2017, Receiving Guests at Home by Nationally Mixed Couples: The Case of Polish Females and Norwegian Males, „Studia Migracyjne - Przegląd Polonijny", t. 43, nr 4, s. 61-86.

Rybczyński Witold, 1996, Dom. Krótka historia idei, tłum. Krystyna Husarska, Wydawnictwo Marabut-Oficyna Wydawnicza Volumen, Gdańsk-Warszawa. 
Schmidt Filip, 2010, Teorie kuchenne. Dialektyka przyzwyczajeń $i$ refleksyjności w koncepcji Jeana-Claude'a Kaufmanna, „Kultura i Społeczeństwo”, nr 1, s. 49-86.

Schmidt Filip, 2015, Para, mieszkanie, matżeństwo. Dynamika związków intymnych na tle przemian historycznych $i$ wspótczesnych dyskusji o procesach indywidualizacji, Wydawnictwo Naukowe UMK, Torun.

Skowrońska Marta, 2015, Jak u siebie. Zamieszkiwanie i komfort, Nomos, Kraków.

Skowrońska Marta, 2019, Czuj sie jak u siebie, ale bez przesady. Kontrola przestrzeni $i$ opieka nad gościem — dwa wymiary asymetrii władzy w sytuacji gościny, w: Bogumiła Mateja-Jaworska, Marta Skowrońska (red.), Gość w dom. Wspótczesne praktyki przyjmowania gości, Wydawnictwo Naukowe UAM, Poznań.

Żadkowska Magdalena, 2012, Para w praniu. O wspótczesnej rodzinie i codziennych czynnościach w socjologii Jeana-Claude'a Kaufmanna, „Studia Socjologiczne”, nr 2, s. 143-165.

Żadkowska Magdalena, 2016, Para w praniu. Codzienność, partnerstwo, obowiazki domowe, Wydawnictwo Uniwersytetu Gdańskiego, Gdańsk.

\title{
FEMININE HOSPITALITY? \\ AN ANALYSIS OF SELECTED HOSPITALITY PRACTICES
}

\author{
Bogumiła Mateja-Jaworska \\ (Adam Mickiewicz University in Poznań)
}

\begin{abstract}
This text contains an analysis of the ways in which men and women engage in selected hospitality practices, including such questions as the feminine transmission of hospitality patterns, the division of responsibilities in preparing for guests, and places for meeting socially (at home and outside the home). On the basis of material gathered by the team of the Archive of Research on Everyday Life, the author finds numerous paradoxes and inconsistencies between women's beliefs and their behaviors. In attempting a theoretical explanation, reference is made to the ideas of Pierre Bourdieu, Jean-Claude Kaufmann, Harriet Bjerrum Nielsen, and Monica Rudberg. Analysis leads to the conclusion that the multiple and time-consuming responsibilities associated with receiving guests mostly fall to women and thus contribute to their ability to sustain symbolic power over the home space. Consequently, hospitality perpetuates the traditional division into what is public and considered "masculine" and what is private or "feminine."
\end{abstract}

Key words: hospitality, hospitality practices, gender, hostess, host, guest, home, privacy

Słowa kluczowe: gościnność, praktyki goszczenia, gender, gospodyni, gospodarz, gość, dom, prywatność 